\title{
Polygenic analysis of ammonia-oxidizing bacteria for completely autotrophic nitrogen removal
}

\author{
Hanyan Zou ${ }^{1}$, Junli Huang ${ }^{2 \star}$, Fang Fang ${ }^{3}$ and Jinsong Guo ${ }^{3}$ \\ ${ }^{1}$ Key Laboratory of Biorheological Science and Technology, Ministry of Education, Chongqing, China. \\ ${ }^{2}$ Bioengineering College, Chongqing University, Chongqing, China. \\ ${ }^{3}$ Key Laboratory of Three Gorges Reservoir Region's Eco-Environment, Ministry of Education, Chongqing, China.
}

Accepted 19 April, 2013

\begin{abstract}
This study investigated the functional microbial community in a sequencing batch biofilm reactor (SBBR) for completely autotrophic nitrogen removal over nitrite (CANON), and analyzed the phylogenetic relationships of the key bacteria, the aerobic ammonia oxidizing bacteria (AOB), with three different markers genes: 16S rDNA, amoA and hao. The resulting tree topologies from all the markers were inclined to consistence with minor discrepancy. 16S rDNA- and hao-based phylogenetic analyses revealed that $A O B$ for completely autotrophic nitrogen removal were related most closely to Nitrosomonas sp., and amoA-based phylogenetic analysis demonstrated AOB had highest similarity with a group of uncultured bacteria, while 88 to $94 \%$ similarity with Nitrosomonas sp. was also achieved. Generally, the detection of three different markers revealed that AOB were closely related to the bacteria of Proteobacteria Nitrosomonas. This study shows that each of the functional markers (16S rDNA, amoA and hao) could be used to trace AOB for completely autotrophic nitrogen removal and it is more accurate if more than two markers are used at a time.
\end{abstract}

Key words: 16S rDNA; amoA, completely autotrophic nitrogen removal; hao; phylogenetic analysis.

\section{INTRODUCTION}

Biological nitrogen removal is generally used for elimination of nitrogen from wastewater since these components can be toxic to aquatic life, and cause oxygen depletion and eutrophication in receiving water (Brauer and Eitzer, 1997). Ammonia is especially abundant in many wastewater streams and its removal is often achieved using nitrification/denitrification systems. Most nitrification/ denitrification systems consist of two steps: aerobic nitrification and anaerobic denitrification, and require two separate reactors (Ahn, 2006). Furthermore, heterotrophic denitrification, widely used in wastewater treatment processes, requires an external organic carbon source to provide electron donors when treating low $\mathrm{C} / \mathrm{N}$ ratio wastewater, or high internal recycle ratios between aerobic reactors when treating high $\mathrm{C} / \mathrm{N}$ ratio wastewater (Aoi et al., 2005). Although the recently developed anaerobic ammonia oxidation (Anammox) reaction has the potential to achieve high ammonia-removal rates at low cost, it requires specific operating conditions and adjustment of the ratio between $\mathrm{NH}_{4}{ }^{+}-\mathrm{N}$ and $\mathrm{NO}_{2}{ }^{-}-\mathrm{N}$ before the Anammox reaction occurs (Aoi et al., 2005).

Recently, completely autotrophic nitrogen removal system, in which simultaneous nitrification and denitrification under aerobic conditions in a single reactor is achieved, has been described and investigated in the laboratories (Gong et al., 2008; Helmer et al., 2001; Olav Sliekers et al., 2003; Strous, 2000; Third et al., 2005). This is performed in a single reactor at oxygen limited conditions, without the production of $\mathrm{N}_{2} \mathrm{O}$ or $\mathrm{NO}$ and with production of $\mathrm{N}_{2}$. In such a system, autotrophic nitrogen removal process was achieved by the close cooperation between 
aerobic ammonia-oxidizing bacteria (AOB) and Anammox bacteria. $A O B$ oxidize ammonia to nitrite, consuming oxygen and creating anoxic conditions that the Anammox bacteria need (Olav Sliekersa et al., 2002). The oxidation of ammonia to nitrite by $A O B$ in wastewater treatment plants (WWTPs) is often considered the most sensitive step in the nitrification process (Purkhold et al., 2000). The oxidation of $\mathrm{NH}_{3}$ is a two-step process catalyzed by ammonia monooxygenase (AMO) and hydroxylamine oxidoreductase (HAO), the key enzymes from AOB (Arp et al., 2002). AMO catalyzes the oxidation of $\mathrm{NH}_{3}$ to $\mathrm{NH}_{2} \mathrm{OH}$ and $\mathrm{HAO}$ catalyzes the oxidation of $\mathrm{NH}_{2} \mathrm{OH}$ to $\mathrm{NO}_{2}^{-}$.

$\mathrm{AOB}$ are obligate chemolithotrophs that derive all of the reductant required for energy and biosynthesis from the oxidation of $\mathrm{NH}_{3}$ to nitrite $\left(\mathrm{NO}_{2}{ }^{-}\right)$. In the $\mathrm{NH}_{4}{ }^{+}$-rich environment, $\mathrm{AOB}$ play an important role by initiating the conversion of $\mathrm{NH}_{3}$ to $\mathrm{N}_{2}$. AOB also have potential applications in the bioremediation of polluted soils and waters through the indiscriminate action of the monooxygenase that initiates nitrification (Painter, 1986). In view of the significance of $A O B$ in nitrogen removal process, they have been investigated by the molecular technique (Aoi et al., 2005; Gong et al., 2008; Rowan et al., 2003). The $16 \mathrm{~S}$ rDNA sequences are suitable for providing a comprehensive long-term evolutionary view of prokaryotic taxonomy because of their conservative characters (Rossello-Mora and Amann, 2001), and have proven useful in the discrimination among organisms (Beja et al., 2002; Hollibaugh et al., 2002; Stephen et al., 1996; Utaker et al., 1995; Weisburg et al., 1991), However, the outcome is confusing when examining a single genus by using $16 \mathrm{~S}$ rDNA (Rotthauwe et al., 1997). For this reason, genes encoding protein, such as amoA which codes for the active site of AMO, have been added to the collection of comparative tools used by taxonomists and molecular ecologists for diversity studies (Aoi et al., 2005; Calvo et al., 2005; Gong et al., 2008; Purkhold et al., 2003), and amoA has been extensively used for the detection and study of ammonia oxidizers, particularly in natural environments (Aakra et al., 2001a; b; Horz et al., 2000; Juretschko et al., 1998; Rotthauwe et al., 1997). In addition, another protein encoding gene, hao, has been considered as a new molecular biological marker for AOB (Shinozaki and Fukui, 2002), because methane-oxidizing bacteria have the particulate methane monooxygenase $(p m o)$ gene which resembles the amo gene (Holmes et al., 1995).

AOB plays a significant role for completely autotrophic nitrogen removal (Aoi et al., 2005; Gong et al., 2008; Guo et al., 2008), however they are very sensitive to the natural environment $(\mathrm{pH}$, temperature etc.) and are hard to isolate (Hermansson and Lindgren, 2001). In our previous study, the sequencing batch biofilm reactor (SBBR) for completely autotrophic nitrogen removal over nitrite (CANON) was developed and the complete conversion of ammonia into $\mathrm{N} 2$ in a single reactor was achieved (Fang et al., 2007; Guo et al., 2009), and the mechanism responsible for completely autotrophic nitrogen removal was studied primarily (Yang et al., 2009), but still knowledge about the community of AOB for SBBR completely autotrophic nitrogen removal is very limited. Of the two groups of important functional bacteria for completely autotrophic nitrogen removal, the dominant Anammox bacteria community has already been identified (Huang et al., 2010). The purpose of this study, therefore, was to investigate the community of $\mathrm{AOB}$ for completely autotrophic nitrogen removal and to analyze the phylogenetic relationships. The phylogenetic tree topologies based on $16 \mathrm{~S}$ rDNA, amoA and hao from AOB for the process were used for phylogenetic relationship analysis, respectively. The phylogenetic trees constructed from each gene were then weighted against the composite sequence dataset to identify the marker that best reproduced the information resulting from the polygenic tree.

\section{MATERIALS AND METHODS}

\section{Total DNA extraction from the sludge}

Details of the SBBR for completely autotrophic nitrogen removal system operation have been described (Guo et al., 2009). The seed sludge samples used for total DNA extraction were obtained from the bottom of the reactor, which had been in a stable operation with $90 \%$ ammonia conversion ration and $80 \%$ total nitrogen removal ration. The total genomic DNA extraction was performed as previously described (Huang et al., 2009) with minor modification. To isolate purified total genomic DNA from the enriched sludge, polyvinylpoly-pyrrolidone was used to remove the humic acid contents. The total genomic DNA was obtained by lysing microbes in the soil sample through a series of lysozyme, sodium dodecyl sulfate, and rapid freeze-thaw treatments.

\section{PCR amplification of 16S rDNA, amoA and hao}

Primers aobF/aobR, amoA-F/amoA-R, and hao-F/hao-R for $16 \mathrm{~S}$ rDNA, amoA and hao, respectively were designed according to the reported nine ammonia oxidizing strains within the $\beta$ subdivision of the Proteobacteria (Head et al., 1993; Woese et al., 1984), usin $g$ the Primer Express 1.0 (PE Applied Biosystems, Foster City, CA, USA). For 16S rDNA, aobF of 5'-CGAAAGATGTGCTAATACCG-3' and aobR of 5'-TGTGAAGCCCTACCCATAA-3' were used. The amplification of $16 \mathrm{~S}$ rDNA partial sequence of $\mathrm{AOB}$ was performed as follows. The reaction volumes $(25 \mu \mathrm{l})$ consisted of $1 \times \mathrm{PCR}$ buffer, $0.2 \mathrm{mmol} \mathrm{I}^{-1} \mathrm{dNTPs}, 0.2 \mu \mathrm{mol} \mathrm{I}^{-1}$ of each of the primers, $0.5 \mathrm{U}$ of pfu polymerase (Promega Corp., Wisconsin, USA) and $1 \mu$ l of the total DNA from the sludge as the templates. The amplification was conducted with an initial denaturing step at $94^{\circ} \mathrm{C}$ for $4 \mathrm{~min}$, followed by 30 cycles $\left(94^{\circ} \mathrm{C}\right.$ for $30 \mathrm{~s}, 62^{\circ} \mathrm{C}$ for $30 \mathrm{~s}, 72^{\circ} \mathrm{C}$ for $2 \mathrm{~min}$ ) and $72^{\circ} \mathrm{C}$ for $5 \mathrm{~min}$ and a final elongation step at $72^{\circ} \mathrm{C}$.

DNA sequence of $a m o A$ was amplified using the following primers: amoA-F (5'-GTGAGTATATTTAGAACGGAAGA-3') and amoA-R (5'-TTTATTTGATCCCCTCTGG-3'). Reactions were performed as described above. The standard thermal profile used for the amplification of the amoA target sequence was as follows: $3 \mathrm{~min}$ at $94^{\circ} \mathrm{C}$, and then 30 cycles consisting of $30 \mathrm{~s}$ at $94^{\circ} \mathrm{C}, 30 \mathrm{~s}$

at $48^{\circ} \mathrm{C}, 2 \mathrm{~min}$ at $72^{\circ} \mathrm{C}$, and a final cycle $5 \mathrm{~min}$ at $72^{\circ} \mathrm{C}$.

The full length sequence of the hao was amplified by using the following primers: hao-F (5'-CGGAGGAGAGAGATGAGAATAG-3') and hao-R (5'- CGGGTCGGTTGTCAGTGCGGT-3'). PCR reactions were performed in $20 \mu \mathrm{l}$ containing $1 \times \mathrm{GC}$ buffer (TaKaRa Shuzo, Shiga, Japan), $0.4 \mathrm{mmol} \mathrm{I}^{-1} \mathrm{dNTPs}, 0.1 \mu \mathrm{mol} \mathrm{I}^{-1}$ of each primer, 0.5 $\mathrm{U}$ of Pfu polymerase (Promega Corp., Wisconsin, USA) and $0.8 \mu \mathrm{l}$ of template DNA. The initial denaturation at $94^{\circ} \mathrm{C}$ for 3 min was 
Table 1. Sequences for 16S rDNA used in this study.

\begin{tabular}{lll}
\hline NCBI GenBank accession number & Organism & Reference \\
\hline AB079053 & Nitrosomonas sp.ENI-11 & Yamagata et al., 1999 \\
GQ451713 & Nitrosomonas europaea strain ATCC 25978 & Woese et al., 1984 \\
AF353160 & Nitrosomonas europaea & Takahashi, et al. Unpublished \\
AB070983 & Nitrosomonas europaea & Shinozaki and Fukui, 2002 \\
AF338211 & Nitrosomonas sp.WH-2 & Voytek, 1996 \\
EU267433 & Uncultured bacterium clone IIEA1-rp-20 Nit & Beier, et al. Unpublished \\
AF210051 & Uncultured $\beta$ proteobacterium HB3 & Baribeau et. al., 2000 \\
DQ988297 & Uncultured bacterium clone LR A2-16 & Yan, Unpublished \\
AF037106 & Nitrosomonas europaea & Juretschko et al., 1998 \\
AB430334 & Uncultured bacterium & Chuang, Unpublished \\
AJ224941 & Nitrosomonas sp. KOIl-21 & van der Meer, Unpublished \\
AY135356 & Ammonia-oxidizing bacterium NS500-9 & Fouratt et. al., 2003 \\
AF363292 & Nitrosomonas sp. DYS317 & Takahashi, et al. Unpublished \\
AF353164 & Nitrosomonas sp. DYS323 & Takahashi, et al. Unpublished \\
AB093545 & Nitrosomonas sp. & Matsuba, et al. Unpublished \\
AF386750 & Nitrosomonas sp. R5c88 & Burrell et. al., 2001 \\
AF386749 & Nitrosomonas sp. R5c47 & Burrell et. al., 2001 \\
AY958676 & Nitrosomonas sp. ML1 & Burrell et.al., 2001 \\
\hline
\end{tabular}

followed by 30 cycles consisting of denaturation at $94^{\circ} \mathrm{C}$ for $30 \mathrm{~s}$, annealing at $60^{\circ} \mathrm{C}$ for $30 \mathrm{~s}$, and extension at $72^{\circ} \mathrm{C}$ for $2 \mathrm{~min}$ and the final extension at $72^{\circ} \mathrm{C}$ for $10 \mathrm{~min}$. Aliquots $(5 \mu \mathrm{l})$ of the PCR products of $16 \mathrm{~S}$ rDNA, amoA and hao were electrophoresed and visualized in $1 \%$ agarose gels by using standard electrophoresis procedures.

\section{Phylogenetic analyses}

The nucleotide sequences for 16S rDNA, amoA and hao genes have been submitted to GenBank database under accession numbers HQ144199, HM473177 and HQ174563, respectively. For phylogenetic analysis, the homologues of $16 \mathrm{~S}$ rDNA (Table 1), amoA (Table 2) and hao (Table 3) genes were retrieved from DDBJ/EMBL/GenBank International Nucleotide Data Banks using 16S rDNA (HQ144199), amoA (HM473177) and hao (HQ174563) as queries, respectively. The collected data was used to construct the phylogenetic trees. Neighbor-joining (NJ) phylogenetic trees for $16 \mathrm{~S}$ rDNA, amoA, and hao genes were generated from the corresponding matrix of nucleotide divergence between sequences using the program MEGA5.0, respectively. Confidence in the branching points was obtained with 100 bootstrap replicates. The GenBank accession numbers for the sequences determined in this study are HQ144199 (sequence for 16S rDNA), HM473177 (sequence for amoA) and HQ174563 (sequence for hao).

\section{RESULTS}

\section{AOB phylogeny inferred from $16 S$ rDNA}

A unique DNA fragment of approximately $1100 \mathrm{bp}$ was amplified by primers aobF/aobR from the total DNA extracted from the sludge in the reactor for completely autotrophic nitrogen removal system (Figure 1). DNA sequence analysis of the fragment of $1074 \mathrm{bp}$ revealed that it was partial sequence of $16 \mathrm{~S}$ rDNA from AOB. Only sequences of more than $98 \%$ in similarity were concerned for phylogenetic analysis (Table 1). The phylogenetic tree based on the similarity of sequences of $16 \mathrm{~S}$ rDNA was constructed (Figure 2). The phylogenetic inference analysis revealed that $\mathrm{AOB}$ for completely autotrophic nitrogen removal formed a monophyletic group with Nitrosomonas sp., multiple sequence alignments that showed highest similarities to Nitrosomonas sp. (99\%). AOB strains having more than $60 \%$ DNA-DNA similarity are considered as members of the same species (Purkhold et al., 2003). According to DNA-DNA similarity data, AOB for completely autotrophic nitrogen removal are members of the same species of Nitrosomonas sp.

\section{AOB phylogeny inferred from amoA}

During the past few years, the gene encoding the active site subunit of amoA has been exploited increasingly as a marker molecule for $A O B$ diversity research in natural and engineered systems. In this study, the full length of $a m o A$ was used to characterize the AOB for completely autotrophic nitrogen removal. The primers amoA-F/ amoA$\mathrm{R}$ produced a fragment of approximately $830 \mathrm{bp}$ (Figure 3 ). The Phylogenetic trees for amoA were calcu-lated from the nucleotide datasets and the $a m o A$ sequence of AOB from completely autotrophic nitrogen removal system showed the highest similarity (99\%) to FJ577880 and FJ577884 (Table 2). The organisms from completely autotrophic nitrogen removal system probably represent a novel lineage in the amoA-based topology. In addition, 88 to $94 \%$ similarity with the amoA gene of Nitrosomonas 
Table 2. Sequences for amoA used in this study.

\begin{tabular}{lll}
\hline $\begin{array}{l}\text { NCBI GenBank } \\
\text { Accession Number }\end{array}$ & Organism & Reference \\
\hline AF058692 & Nitrosomonas europaea & Homes, 1998) \\
L08050 & Nitrosomonas europaea & McTavish et al., 1993 \\
AF058691 & Nitrosomonas europaea & Homes, 1998 \\
AB079055 & Nitrosomonas sp. ENI-11 & Hirota et al., 2000 \\
AB079054 & Nitrosomonas sp. ENI-11 & Hirota et al., 2000 \\
AF037107 & Nitrosomonas europaea & Juretschko et al., 1998 \\
AF037108 & Nitrosococcus mobilis & Juretschko et al., 1998 \\
AJ538124 & Uncultured soil bacterium, clone SC-MGR-P2K119 & Grimm, Unpublished \\
AJ539318 & Uncultured soil bacterium, clone SC-MGR-R2K04 & Grimm, Unpublished \\
AJ538121 & Uncultured soil bacterium, clone SC-MGR-P2K116 & Grimm, Unpublished \\
AJ538111 & Uncultured soil bacterium, clone SC-MGR-PK107 & Grimm, Unpublished \\
EU010401 & Uncultured bacterium clone JJY-amoA-1FF-001 & Bae, Unpublished \\
U51630 & Nitrosomonas eutropha & Norton et al., 2002 \\
AB031869 & Nitrosomonas sp. TK794 & Yokoyama, 1997 \\
AY177932 & Nitrosomonas eutropha & Avrahami et. al., 2003 \\
FJ577884 & Uncultured bacterium clone amoA_SBR_JJY_70 & Bae, Unpublished \\
FJ577880 & Uncultured bacterium clone amoA_SBR_JJY_61 & Bae, Unpublished \\
AF202649 & AmoA anoxic biofilm clone S6 & Schmid et al., 2000 \\
GU121142 & Uncultured bacterium isolate DGGE gel band M23 & Yu, Unpublished \\
AF532304 & Uncultured ammonia-oxidizing bacterium clone RI-5a & Nogueira et al., 2002 \\
AF202654 & AmoA anoxic biofilm clone S3 & Schmid et al., 2000 \\
FJ577855 & Uncultured bacterium clone amoA_SBR_JJY_24 & Bae, Unpublished \\
GQ255557 & Uncultured ammonia-oxidizing bacterium clone P44-F5-SP6 & Dong, Unpublished \\
\hline
\end{tabular}

Table 3. Sequences for hao used in this study.

\begin{tabular}{lll}
\hline $\begin{array}{l}\text { NCBI GenBank } \\
\text { accession number }\end{array}$ & Organism & Reference \\
\hline AB030385 & Nitrosomonas sp. ENI-11 & (Hirota et al., 2000) \\
AB030386 & Nitrosomonas sp. ENI-11 & (Hirota et al., 2000) \\
AB030387 & Nitrosomonas sp. ENI-11 & (Hirota et al., 2000) \\
U04053 & Nitrosomonas europaea & (Sayavedra-Soto et al., 1994) \\
FM163618 & Uncultured planctomycete, clone P17 & (Schmid et al., 2008) \\
FJ493766 & Uncultured Nitrosomonas sp. clone ISA01354 & Chen,C.L., Unpublished \\
FJ493761 & Uncultured Nitrosomonas sp. clone ISA01349 & Chen,C.L., Unpublished \\
\hline
\end{tabular}

sp. was achieved, which demonstrated AOB for completely autotrophic nitrogen removal were also closely related to the bacteria of the $\beta$ subclass of the Proteobacteria, Nitrosomonas.

\section{AOB phylogeny inferred from hao}

With the extending dataset and an increasing number of closely related $a m o A$ sequences, the limitation of the amoA approach as applied now becomes more apparent. Although $\mathrm{AOB}$ pure cultures or $\mathrm{AOB}$ in environmental samples can be assigned rapidly to some phylogenetic subgroups within this guild by using the amoA approach, the amoA fragment analysed does provide less resolution. In this study, therefore, AOB for completely autotrophic nitrogen removal were further analysed by a new marker, the hao gene.

The protein coding gene, hao, is $1713 \mathrm{bp}$ in length and is expressed as a monocistronic transcript (SayavedraSoto et al., 1994). In this study, the full length sequence of hao, approximately $1700 \mathrm{bp}$, was produced by primers hao-F/hao-R (Figure 5). The hao-based phylogenetic tree demonstrated that AOB for completely autotrophic nitrogen removal are related most closely to "Nitrosomonas sp. ENI-11" (Table 3 and Figure 6). The close relationship 


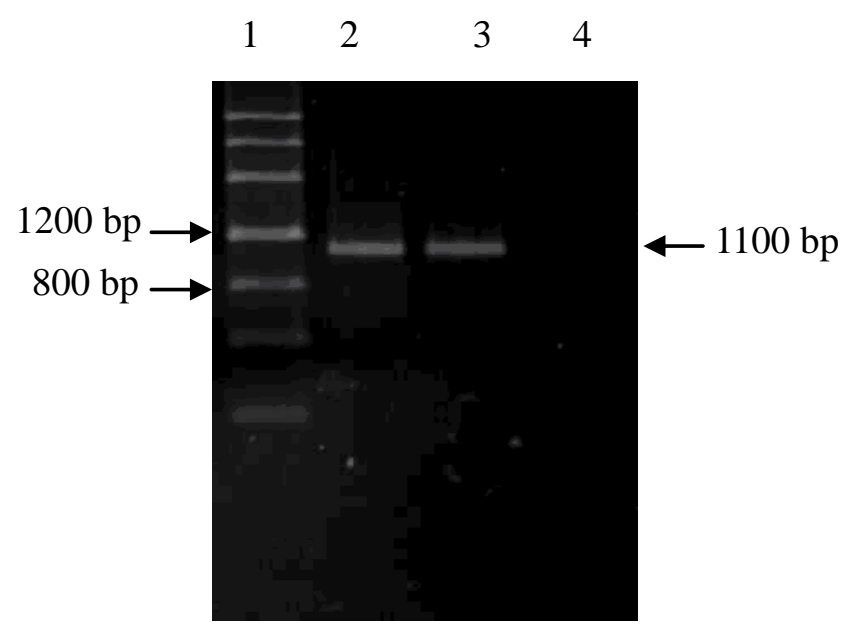

Figure 1. PCR amplification of $16 \mathrm{~S}$ rDNA partial sequence from uncultured ammonia-oxidizing bacteria for completely autotrophic nitrogen removal. 1, DNA Marker (TIANGEN Biotech, Beijing, China); 2-3, partial sequence for 16S rDNA of ammonia-oxidizing bacterium by PCR; 4, Negative control.

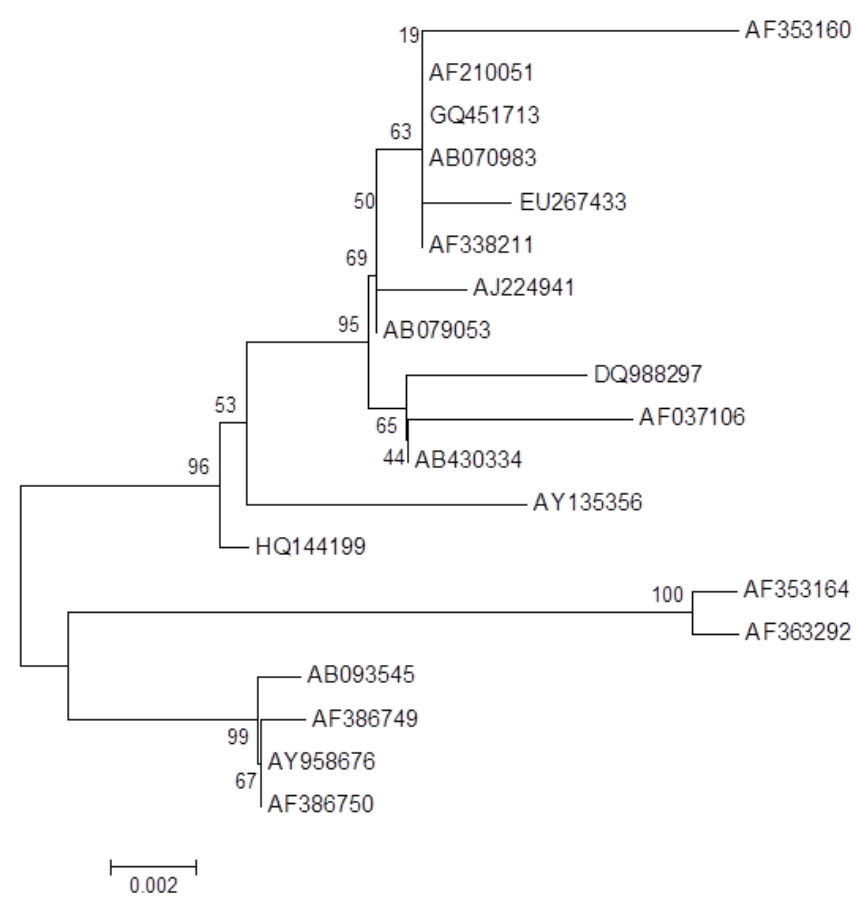

Figure 2. 16S rDNA-based phylogenetic tree of the ammoniaoxidizing bacteria (AOB) for completely autotrophic nitrogen removal and its relatives. The tree includes all isolates for which 16S rDNA gene sequences have higher than $98 \%$ of similarities with that of AOB (HQ144199). GenBank accession numbers in the tree represent different organisms (Table 1).Confidence in the branching points was obtained with 100 bootstrap replicates. Most of the nodes are supported with high bootstrap values $(>60 \%)$.

between $A O B$ for completely autotrophic nitrogen removal and Nitrosomonas sp. is also reflected by their high DNADNA similarity.



Figure 3. PCR amplification of amoA from uncultured ammoniaoxidizing bacteria for completely autotrophic nitrogen removal.1, DNA Marker (TIANGEN Biotech, Beijing, China); 2-3, amoA of ammonia-oxidizing bacterium by PCR; 4 , Negative control.

\section{DISCUSSION}

The autotrophic ammonia-oxidizing bacteria $(\mathrm{AOB})$ do not represent a monophyletic clade but are members of at least two phylogenetically different groups. The first group is characterized by the members of Nitrosomonas-Nitrosospira clade in the $\beta$ subclass of the Proteobacteria, and the second group is characterized by the strains of the species Nitrosococcus oceanus, and probably, Nitrosococcus halophilus in the y subclass of the Proteobacteria (Rotthauwe et al., 1997). The first group exists widely in the environment (Belser, 1979), and in this study, the results show that the "Nitrosomonas" clade of the $\beta$ proteobacteria AOB existed in completely autotrophic nitrogen removal system.

The phylogenetic tree is a tool which analyzed the phylogenetic relationship of unknown samples in environment. Distance-based neighbor-joining method was used to construct the phylogenetic tree in this study. Though maximum parsimony trees were found to be more accurate than distance-based neighbor-joining method to analyze the AOB (Calvó et al., 2005), the neighbor-joining method was more widely used (Aakra et al., 2001a; Purkhold et al., 2000; Purkhold et al., 2003; Tabei and Ueno, 2010), and neighbor-joining method is proposed for reconstructing phylogenetic trees from evolutionary distance data (Saitou and Nei, 1987). In this study, the $16 S$ rDNA, amoA and hao-based phylogenetic trees were constructed. The 16S rDNA and hao genes sequences determined showed highest similarities (99\%) to sequences of Nitrosomonas sp., and the $a m o A$ gene sequences determined demonstrated highest similarity (99\%) to sequences of a new group of "uncultured bacterium", and was also closely related to Nitrosomonas sp. (88 to $94 \%$ of similarity).

The phylogenetic relationship of $\mathrm{AOB}$ in the environment has been investigated based on the 16S rDNA and amoA previously (Purkhold et al., 2000; Purkhold et al., 2003), while this is the first report to characterize AOB for completely autotrophic nitrogen removal with three differ- 


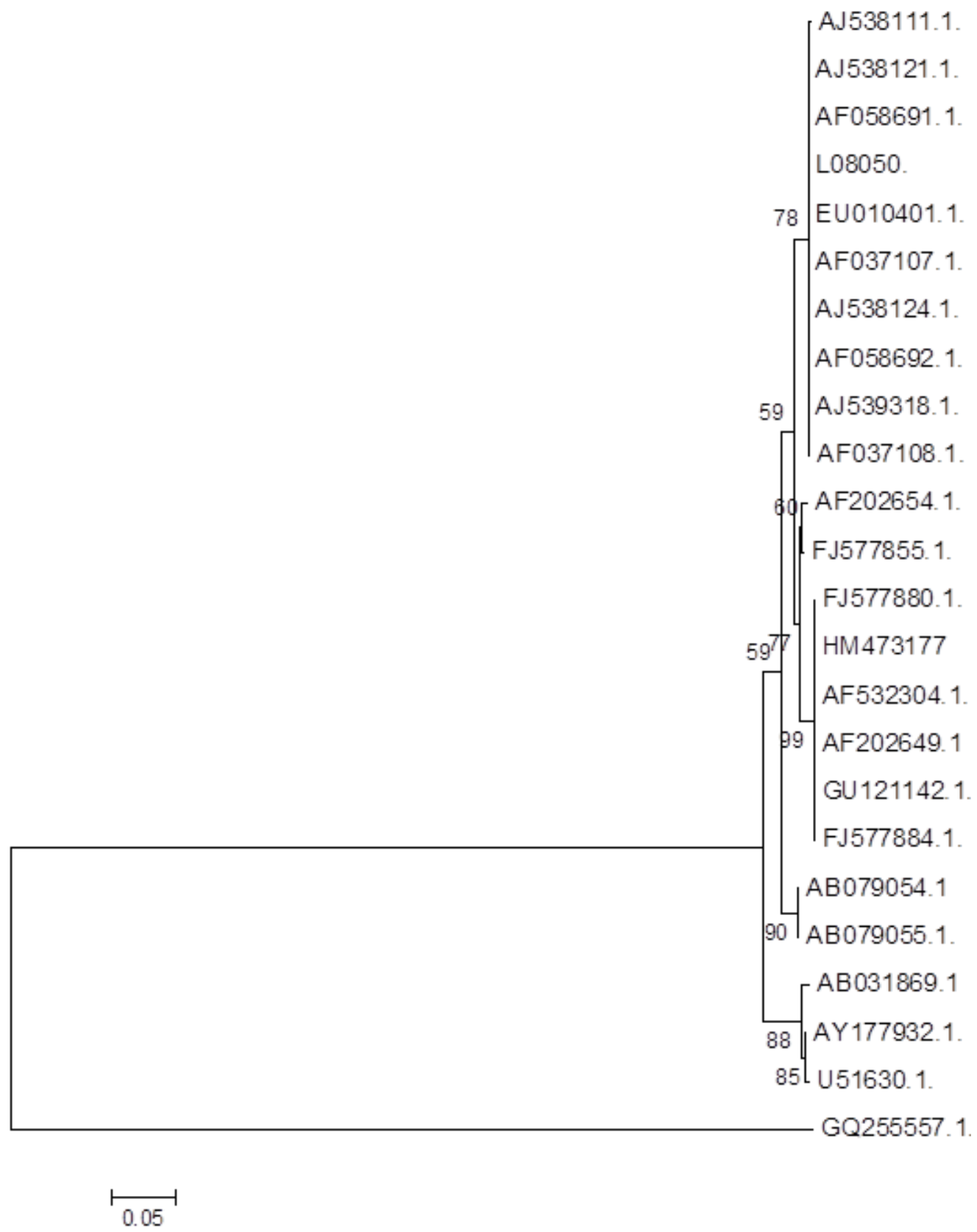

Figure 4. aomA-based phylogenetic tree of the ammonia-oxidizing bacteria for completely autotrophic nitrogen removal and its relatives. The tree includes all isolates for which amo $A$ has higher than $88 \%$ of similarity with that of AOB (HM473177). GenBank accession numbers in the tree represent different organisms (Table 2). Confidence in the branching points was obtained with 100 bootstrap replicates. Most of the nodes are supported with high bootstrap values $(>50 \%)$.

rent markers $16 \mathrm{~S}$ rDNA, amoA and hao genes. Taken together, topologies of $16 \mathrm{~S}$ rDNA and hao-based trees were similar, but inconsistent affiliations were also found in the amoA -based tree (Figures 2, 4 and 6). The 16S rDNA and hao-based phylogenetic analysis revealed that AOB for completely autotrophic nitrogen removal belong to Nitrosomonas sp., while the amoA-based topology showed the members are related most closely to uncul- tured bacteria, while higher similarity ( 88 to $94 \%$ ) with Nitrosomonas sp. was also achieved. Previous results demonstrated a superior resolution of 16S rDNA and amoA analysis (Purkhold et al., 2003). Comparison of 16S rDNA, amoA and hao gene in chemolithotrophic $\mathrm{AOB}$ showed that the hao gene is more useful than the amoA gene as a molecular biological marker for $A O B$ detection from environmental samples (Shinozaki and 


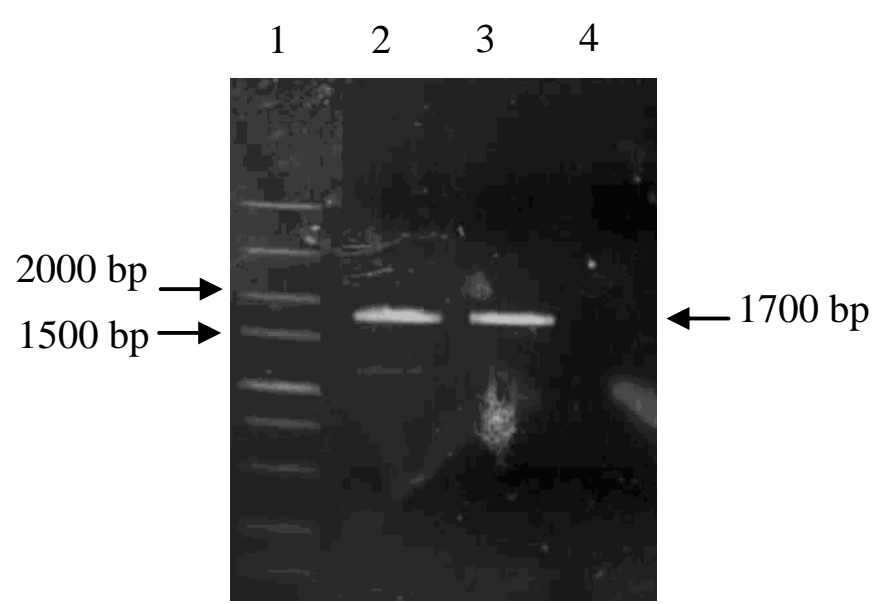

Figure 5. PCR amplification of hao from uncultured ammoniaoxidizing bacteria for completely autotrophic nitrogen removal. 1, DL5000 DNA Marker (TIANGEN Biotech, Beijing, China); 2-3, hao of ammonia-oxidizing bacterium by PCR; 4 , Negative control.
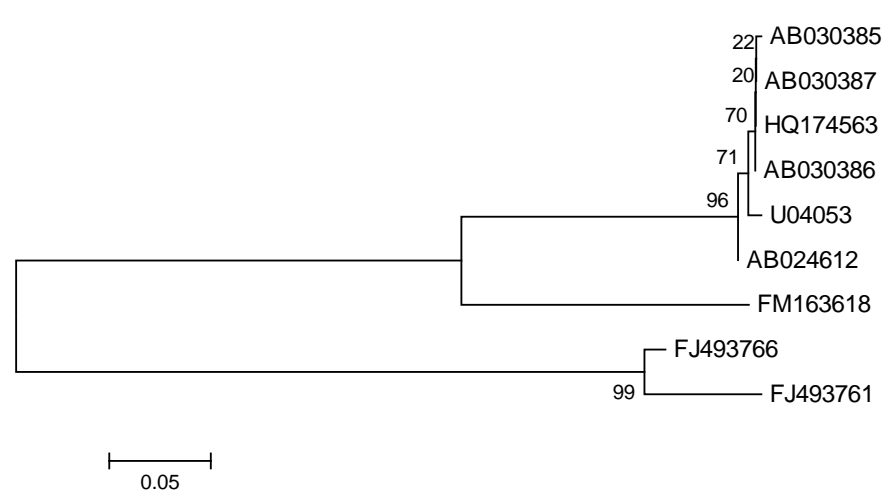

Figure 6. hao-based phylogenetic tree of the ammonia-oxidizing bacteria for completely autotrophic nitrogen removal and its relatives. The tree includes all isolates for which hao has higher than $81 \%$ of similarities with that of AOB (HQ174563). GenBank accession numbers in the tree represent different organisms (Table 3). Confidence in the branching points was obtained with 100 bootstrap replicates. Most of the nodes are supported with high bootstrap values (>70\%).

Fukui, 2002), because methane-oxidizing bacteria have the particulate methane monooxygenase (pmo) gene which resembles the amo gene (Holmes et al., 1995) and a sequence similar to the hao gene has not been reported in other organisms. Therefore, the hao gene may be used in the future if the database of this gene is expanded appropriately. In this study, the hao gene was first used as a marker to identify AOB for completely autotrophic nitrogen removal and proved its practicability.

\section{ACKNOWLEDGEMENTS}

This work was supported by the Natural Science Foundation of China (No.50608071).

\section{REFERENCES}

Aakra A, Utaker JB, Nes IF (2001a). Comparative phylogeny of the ammonia monooxygenase subunit $A$ and $16 \mathrm{~S}$ rRNA genes of ammonia-oxidizing bacteria. FEMS Micobiol. Lett. 205:237-242.

Aakra A, Utaker JB, Pommerening-Röser A, Koops HP, Nes IF (2001b). Detailed phylogeny of ammonia-oxidizing bacteria determined by rDNA sequences and DNA homology values. Int. J. Syst. Evol. Microbiol. 51:2021-2030.

Ahn YH (2006). Sustainable nitrogen elimination biotechnologies: a review. Process Biochem. 41:1709-1721.

Aoi Y, Shiramasa Y, Kakimoto E, Tsuneda S, Hirata A, Nagamune T (2005). Single-stage autotrophic nitrogen-removal process using a composite matrix immobilizing nitrifying and sulfur-denitrifying bacteria. Appl. Microbiol. Biotechnol. 68:124-130.

Arp DJ, Sayavedra LA, Hommes NG (2002). Molecular biology and biochemistry of ammonia oxidation by Nitrosomonas europaea. Arch. Microbiol. 178:250-255.

Avrahami S, Liesack W, Conrad R (2003). Effects of temperature and fertilizer on activity and community structure of soil ammonia oxidizers. Environ. Microbiol. 5:691-705.

Baribeau H, Kinner CA, Stephen JR, de Leon R, Rochelle PA, Clark DL (2000). Microbial population characterization of suspended and fixed biomass in drinking water. In American Water Works Association Water Quality Technology Conference. Salt Lake City, UT, USA.

Beja O, Koonin E, Aravind L, Taylor L, Seitz H, Stein J, Bensen D, Feldman R, Swanson R, Delong E (2002). Comparative genomic analysis of archaeal genotypic variants in a single population and in two different oceanic provinces. Appl. Environ. Microbiol. 68:335-345.

Belser LW (1979). Population ecology of nitrifying bacteria. Annu. Rev. Microbiol. 33:309-333.

Brauer M, Eitzer B (1997). Novel nitrogen removal. Water Sci. Technol. 31:447A.

Burrell PC, Phalen CM, Hovanec TA (2001). Identification of bacteria responsible for ammonia oxidation in freshwater aquaria. Appl. Environ. Microbiol. 67:5791-5800.

Calvo L, Cortey M, García-Marin J, Garcia-Gil L (2005). Polygenic analysis of ammonia-oxidizing bacteria using 16S rDNA, amoA, and amoB genes. Int. Microbiol. 8:103-110.

Fouratt MA, Rhodes JS, Smithers CM (2003). Application of temperature gradient gel electrophoresis to the characterization of a nitrifying bioaugmentation product. FEMS Microbiol. Ecol. 43:277286.

Gieseke A, Purkhold U, Wagner M, Amann R, Schramm A (2001). Community structure and activity dynamics of nitrifying bacteria in a phosphate-removing biofilm. Appl. Environ. Microbiol. 67:1351-1362.

Gong Z, Liu S, Yang F, Bao H, Furukawa KJ (2008). Characterization of functional microbial community in a membrane-aerated biofilm reactor operated for completely autotrophic nitrogen removal. Bioresour. Technol. 99:2749-2756.

Guo J, Qin Y, Fang F, Yang G (2008). Isolation, identification and characterization of nitroso-bacteria in one-step completely nitrogen removal process (in Chinese). Acta Microbiol. Sinica. 48: 1088-1094.

Guo J, Yang G, Fang F, Qin Y (2009). Study of the influence of temperature and $\mathrm{pH}$ value on CANON process. Chin. J. Environ. Eng. 3:22-26.

Head IM, Hiorns WD, Embley TM, McCarthy AJ, Saunders JR (1993). The phylogeny of autotrophic ammonia-oxidizing bacteria as determined by analysis of $16 \mathrm{~S}$ ribosomal RNA gene sequences. J. Gen. Microbiol. 139:1147-1153.

Helmer C, Tromm C, Hippen A, Rosenwinkel KH, Seyfried CF, Kunst S (2001). Single stage biological nitrogen removal by nitrification and anaerobic ammonium oxidation in biofilm systems. Water Sci. Technol. 43:311-320.

Hermansson A, Lindgren PE (2001). Quantification of ammoniaoxidizing bacteria in arable soil by real-time PCR. Appl. Environ. Microbiol. 67: 972-976.

Hiorns WD, Hastings RC, Head IM, McCarthy AJ, Saunders JR, Pickup R, WHall GH (1995). Amplification of 16 S ribosomal RNA genes of autotrophic ammonia-oxidizing bacteria demonstrates the ubiquity of nitrosospiras in the environment. Microbiol. 141:2793-2800.

Hirota R, Yamagata A, Kato J, Kuroda A, Ikeda T, Takiguchi N, Ohtake 
H (2000). Physical map location of the multicopy genes coding for ammonia monooxygenase and hydroxylamine oxidoreductase in the ammonia-oxidizing bacterium Nitrosomonas sp. strain ENI-11. J. Bacteriol. 182:825-828.

Hollibaugh JT, Bano N, Ducklow HW (2002). Widespread distribution in polar oceans of a $16 \mathrm{~S}$ rRNA gene sequence with affinity to Nitrosospira-like ammonia-oxidizing bacteria. Appl. Environ. Microbiol 68:1478-1484.

Holmes AJ, Costello A, Lidstrom ME, Murrell JC (1995). Evidence that particulate methane monooxygenase and ammonia monooxygenase may be evolutionarily related. FEMS Microbiol. Lett. 132:203-208.

Homes NG (1998). Mutagenesis and expression of amo, which codes for ammonia monooxygenase in Ntrosomonas europaea. J. Bacteriol 180:3353-3359.

Horz HP, Rotthauwe JH, Lukow T, Liesack W (2000). Identification of major subgroups of ammonia-oxidizing bacteria in environmental samples by T-RFLP analysis of amoA PCR products. J. Microbiol. Methods 39: 197-204.

Huang J, Wu J, Li C, Xiao C, Wang G (2009). Specific and sensitive detection of Ralstonia solanacearum in soil with quantitative, realtime PCR assays. J. Appl. Microbiol. 107:1729-1739.

Huang J, Zou H, wang G, Fang F, Guo J (2010). Molecular biology identification of ANAMMOX bacteria in single-stage autotrophic nitrogen removal system (in Chinese). J. China Biotechnol. 30:60-64.

Juretschko S, Timmermann G, Schmid M, Schleifer KH, PommereningRöser A, Koops HP, Wagner M (1998). Combined molecular and conventional analyses of nitrifying bacterium diversity in activated sludge: Nitrosococcus mobilis and Nitrospira-like bacteria as dominant populations. Appl. Environ. Microbiol. 64:3042-305

McTavish H, Fuchs JA, Hooper AB (1993). Sequence of the gene coding for ammonia monooxygenase in Nitrosomonas europaea. $\mathrm{J}$. Bacteriol. 175:2436-2344.

Nogueira R, Melo LF, U. P, Wuertz S, Wagner M (2002). Nitrifying and heterotrophic population dynamics in biofilm reactors: effects of hydraulic retention time and the presence of organic carbon. Water Res. 36:469-481.

Norton JM, Alzerreca JJ, Suwa Y, Klotz MG (2002). Diversity of ammonia monooxygenase operon in autotrophic ammonia-oxidizing bacteria. Arch Microbiol. 177:139-149.

Olav Sliekersa A, Derwort N, Campose Gomez JL, Strousa M, Kuenena JG, Jettena MSM (2002). Completely autotrophic nitrogen removal over nitrite in one single reactor. Water Res. 36:2475-2482.

Painter HA (1986). Nitrification in the treatment of sewage and waste waters. In Nitrification, (ed. J. I. Prosser). pp. 185-211. Oxford: IRL Press.

Purkhold U, Pommerening-Röser A, Juretschko S, Schmid MC, Koops HP, Wagner M (2000). Phylogeny of all recognized species of ammonia oxidizers based on comparative 16S rRNA and amoA sequence analysis: implications for molecular diversity surveys. Appl. Environ. Microbiol. 66:5368-5382.

Purkhold U, Wagner M, Timmermann G, Pommerening-Röser A, Koops HP (2003). 16S rRNA and amoA-based phylogeny of 12 novel betaproteobacterial ammonia-oxidizing isolates: extension of the dataset and proposal of a new lineage within the Nitrosomonas. Int. J. Syst. Ecol. Microbiol. 53:1485-1494.

Rossello-Mora R, Amann R (2001). The species concept for prokaryotes. FEMS Microbiol. Rev. 25:39-67.

Rotthauwe JH, Witzel KP, Liesack W (1997). The ammonia monooxygenase structural gene amoA as a functional marker, molecular finescale analysis of natural ammonia-oxidizing populations. Appl. Environ. Microbiol. 63:4704-4712.

Rowan AK, Snape JR, Fearnside D, Barer MR, Curtis TP, Head IM (2003). Composition and diversity of ammonia-oxidizing bacterial communities in wastewater treatment reactors of different design treating identical wastewater. FEMS Microbiol. Ecol. 43:195-206.

Saitou NNei M (1987). The Neighbor-joining method: a new method for reconstructing phylogenetic trees. Mol. Biol. Evol. 4:406-425.

Sayavedra-Soto LA, Hommes NG, Arp DJ (1994). Characterization of the gene encoding hydroxylamine oxidoreductase in Nitrosomonas europaea. J. Bacteriol. 176:504-510.
Schmid M, Twachtmann U, Klein M, Strous M, Juretschko S, Jetten M, Metzger JW, Schleifer KH, Wagner M (2000). Molecular evidence for genus level diversity of bacteria capable of catalyzing anaerobic ammonium oxidation. Syst. Appl. Microbiol. 23:93-106.

Schmid MC, Hooper AB, Klotz MG, Woebken D, Lam P, Kuypers MMM, Pommerening-Roeser A, Op den Camp HJ, Jetten MSM (2008). Environmental detection of octahaem cytochrome c hydroxylamine/hydrazine oxidoreductase genes of aerobic and anaerobic ammonium-oxidizing bacteria. Environ. Microbiol. 10:31403149.

Shinozaki HF, ukui M (2002). Comparison of 16S rRNA, ammonia monooxygenase subunit $A$ and hydroxylamine oxidoreductase gene, in chemolithotrophic ammonia-oxidizing bacteria. J. Gen. Appl. Microbiol. 48:173-176.

Sliekers AO, Third KA, Abma W, Kuenen JG, Jetten MSM (2003). CANON and Anammox in a gas-lift reactor. FEMS Microbiol. Lett. 218:339-344.

Stephen JR, McCaig AE, Smith Z, Prosser JI, Embley TM (1996). Molecular diversity of soil and marine 16S rRNA gene sequences related to $\beta$-subgroup ammonia-oxidizing bacteria. Appl. Environ. Microbiol. 62:4147-4154.

Strous M (2000). Anammox and nitrification in: microbiology of anaerobic ammonium oxidation, vol. Dr., pp. 63-81. Netherlands.

Tabei Y, Ueno K (2010). Phylogenic analysis of bacteria passed through 0.45-microm-pore-size filters in the rhizosphere. J. Gen. Appl. Microbiol. 56:129-36.

Third KA, Paxman J, Schmid M, Strous M, Jetten MS, Cord-Ruwisch R (2005). Enrichment of anammox from activated sludge and its application in the CANON process. Microbiol. Ecol. 49:236-244.

Third KA, Sliekers AO, Kuenen JG, Jetten MSM (2001). The CANON system (Completely Autotrophic Nitrogen-removal Over Nitrite) under ammonium limitation: interaction and competition between three groups of bacteria. Syst. Appl. Microbiol. 24:588-596.

Thompson JD, Higgins DG, Gibson TJ (1994). CLUSTAL W: improving the sensitivity of progressive multiple sequence alignment through sequence weighting, position-specific gap penalties and weight matrix choice. Nucleic Acids Res. 22:4673-4680.

Utaker J, Bakken L, Jiang QNes I (1995). Phylogenetic analysis of seven new isolates of ammonia-oxidizing bacteria based on $16 \mathrm{~S}$ rRNA gene sequences. Syst. Appl. Microbiol. 18: 549-559.

Voytek MA (1996). Relative abundance and species diversity of autotrophic ammonia-oxidizing bacteria in aquatic systems. In Water Resources Division. Santa Cruz: University of California.

Wagner M, Rath G, Amann R, Koops HP, Schleifer KH (1995). In situ identification of ammonia-oxidizing bacteria. Syst. Appl. Microbiol. 18:251-264.

Weisburg WG, Barns SM, Pelletier DA, Lane DJ (1991). 16S ribosomal DNA amplification for phylogenetic study. J. Bacteriol. 173:697-703.

Woese CR, Stackebrandt E, Weisburg WG, Paster BG, Madigan MT, Fowler VJ, Hahn CM, Blanz P, Gupta R, Nealson KH, Fox GE (1984). The Phylogeny of purple bacteria: the alpha subdivision. Syst. Appl. Microbiol. 5:316-326.

Yamagata A, Kato J, Hirota R, Kurado A, Ikeda T, Takiguchi NO, htake $H$ (1999). Isolation and characterization of two cryptic plasmids in the ammonia-oxidizing bacterium Nitrosomonas sp. strain ENI-11. J. Bacteriol. 181:3375-3381.

Yokoyama K, Kimura H, Shinozaki HT, Ajima S (1997). Detection of amo gene of chemolithotrophic ammonia-oxidizers in soil by nested PCR. In Plant nutrition for sustainable food production and environment, eds. T. Ando K. Fujita T. Mae H. Matsumoto S. Mori and J. Sekiya), pp. 753-754. Dordrecht: Kluwer Academic Publishers. 